\title{
Determination of Optimum $\mathrm{pH}$ and Contact Time from the Adsorption Process of $\mathrm{Cu}(\mathrm{II})$ Ions by Corn Cob (Zea mays) Biomass
}

\section{*Riska Tri Windiastuti \& Tri Santoso}

Pendidikan Kimia/FKIP - Universitas Tadulako, Palu - Indonesia 94119

Received 17 September 2020, Revised 21 October 2020, Accepted 18 November 2020

doi: 10.22487/j24775185.2020.v9.i4.pp224-229

\begin{abstract}
The use of $\mathrm{Cu}$ in daily life and industry can produce toxic waste, both for the human body and the environment. This study aimed to determine the optimum $\mathrm{pH}$ value and contact time, and the maximum capacity of the adsorption process of Cu(II) ions by corn cob biomass. The optimum $p H$ and contact time were determined based on the adsorption graph of the adsorbent obtained from the optimization of $\mathrm{pH}$ and time, while the maximum adsorption capacity was determined using the Langmuir adsorption isotherm equation. The results showed that the optimum $p H$ adsorption of $\mathrm{Cu}$ (II) ions by corn cob absorbent occurred at $\mathrm{pH} 7$ with the absorption of $98.34 \%$. Optimum contact time occurred at the 60th minute with the percentage of copper absorbed was $96.37 \%$. Besides, the maximum capacity adsorption of corn cobs toward Cu(II) ions was $2.416 \mathrm{mg} / \mathrm{g}$. This study concluded that corn cobs can be used as an adsorbent of Cu(II) ions.
\end{abstract}

Keywords: Cu metal, corn cob, adsorption

\section{Pendahuluan}

Tembaga merupakan logam merah muda, lunak, liat dan dapat ditempa dengan lambang unsurN $\mathrm{Cu}$. Tembaga termasuk sebagai logam berat karena memiliki massa jenis yang lebih besar dari $5 \mathrm{~g} / \mathrm{cm}^{3}$ yaitu, sebesar $8,9 \mathrm{~g} / \mathrm{cm}^{3}$ (Muchtaridi, 2016). Senyawa tembaga yang banyak diketahui yaitu, $\mathrm{Cu}(\mathrm{II})$ yang umumya berwarna biru, baik dalam bentuk hidrat, padat, maupun dalam larutan air. Ion $\mathrm{Cu}(\mathrm{II})$ dalam jumlah sedikit merupakan nutrien yang penting bagi kehidupan manusia dan tanaman tingkat rendah (Svehla, 1990).

Logam $\mathrm{Cu}$ banyak digunakan dalam kabel listrik karena logam $\mathrm{Cu}$ merupakan salah satu konduktor listrik yang baik. Selain itu juga, banyak pabrik industri kimia yang menggunakan jenis logam $\mathrm{Cu}$ sebagai bahan pembuatan logam lain, seperti kuningan (campuran antara tembaga dan seng) (Nurmalasari, dkk., 2015). Penggunaan logam $\mathrm{Cu}$ pada suatu industri tentunya juga akan menghasilkan limbah-limbah logam $\mathrm{Cu}$ tersebut. Limbah-limbah yang mengandung logam berat perlu mendapatkan penanganan yang khusus, mengingat dalam konsentrasi yang tinggi logam tembaga dapat bersifat racun (Widodo, 2008). Banyaknya jumlah logam $\mathrm{Cu}$ pada tubuh manusia dapat mengakibatkan terjadinya keracunaan, hal ini disebabkan terjadinya interaksi antara logam $\mathrm{Cu}$ dengan zat lain yang terdapat dalam tubuh manusia (Nuriadi, dkk., 2013).
Keberadaan logam-logam berat seperti tembaga, kadmium dan timbal dapat merusak lingkungan seperti rusaknya struktur tanah akibat tingkat toksisitas logam yang tinggi (Lelifajri, 2010). Limbah logam $\mathrm{Cu}$ menimbulkan dampak yang sangat besar bagi lingkungan dan manusia, maka perlu dilakukan suatu penanganan lebih lanjut. Salah satu penanganan yang dapat dilakukan untuk mengurangi limbah logam $\mathrm{Cu}$ yaitu dengan metode adsorpsi menggunakan biomassa sebagai adsorben. Metode ini sangat banyak digunakan dalam penangan limbah karena lebih ramah lingkungan, mudah untuk dilakukan serta dapat menggunakan bahan yang mudah ditemui (Sukardjo, 2013).

Biomassa merupakan senyawa makromolekul alami yang berasal dari organisme atau mahluk hidup (Amin, dkk., 2016). Biomassa yang digunakan dalam metode adsorpsi dapat diperoleh dari tanaman maupun limbah industri yang mengandung karbon (Amiruddin, 2016). Tongkol jagung merupakan salah satu limbah yang menarik untuk diteliti sebagai bahan baku pembuatan biomassa karena merupakan salah satu tanaman yang banyak terdapat di Indonesia .

Perkembangan produksi tanaman jagung mengalami peningkatan pertumbuhan sehingga tanaman jagung saat ini sangat mudah untuk ditemui karena penggunaannya terutama dalam bidang makanan (Ligawati, 2016). Tongkol jagung mengandung $44,9 \%$ selulosa sedangkan batang tanaman jagung mengandung selulosa $42,6 \%$ (Veeramachineni, dkk., 2016). Tingginya

*Correspondence:

Riska Tri Windiastuti

e-mail: riskatriwindiastuti@gmail.com

(c) 2020 the Author(s) retain the copyright of this article. This article is published under the terms of the Creative Commons Attribution License 4.0, which permits unrestricted non-commercial use, distribution, and reproduction in any medium, provided the original work is properly cited. 
presentase selulosa yang mengandung gugus hidroksil $(\mathrm{OH})$ pada tongkol jagung, maka tongkol jagung dapat digunakan sebagai biomassa yang selanjutnya akan dijadikan sebagai absorben dalam metode adsorpsi pada limbah logam Cu (Surono, 2010).

Tulisan ini dimaksudkan untuk mendeskripsikan tentang penentuan $\mathrm{pH}$ dan waktu kontak optimum dari proses adsorpsi ion logam $\mathrm{Cu}$ (II) dengan biomassa tongkol jagung (Zea mays).

\section{Metode}

Alat yang digunakan pada penelitian ini yaitu neraca digital, pipet tetes, gelas ukur, gelas kimia, cawan porselin, labu ukur, batang pengaduk, spatula, lumpang dan alu, ayakan $250 \mu \mathrm{m}$ atau 60 mesh, oven, blender, spektrofotometri serapan atom (GBC 932 AA), pipet ukur, kertas saring Whatman nomor 42, botol semprot, shaker linear, alumunium foil dan $\mathrm{pH}$ meter. Bahan yang digunakan pada penelitian ini yaitu tongkol jagung, padatan tembaga, aquades, tissue, larutan $\mathrm{HCl}$ (Merck), larutan $\mathrm{NaOH}$ (Merck).

Variabel penelitian yang digunakan yakni tingkat keasaman ( $\mathrm{pH})$ pada $\mathrm{pH} 1,3,5,7$ dan 9 serta pada waktu kontak 30, 45, 60, 75, 90, dan 105 menit.

\section{Preparasi Adsorben Tongkol Jagung}

Tongkol jagung dibersihkan dari pengotor, selanjutnya dicuci dan dijemur di bawah sinar matahari selama 2 hari. Tongkol jagung dihaluskan menggunakan alat penggiling. Langkah selanjutnya serbuk tongkol jagung yang telah halus diayak menggunakan ayakan 60 mesh. Tongkol jagung di keringkan kembali menggunakan oven pada suhu $100{ }^{\circ} \mathrm{C}$ selama 2 jam. Tongkol jagung dicuci dengan aquades kemudian mengeringkan didalam oven dengan suhu $100{ }^{\circ} \mathrm{C}$ selama 1 jam (Ningsih dkk., 2016).

\section{Pembuatan Larutan Tembaga}

1000 ppm larutan tembaga dibuat dengan cara melarutkan 0,1 gram Kristal tembaga (II) sulfat $\left(\mathrm{CuSO}_{4} \cdot 5 \mathrm{H}_{2} \mathrm{O}\right)$ dalam aquades hingga $100 \mathrm{~mL}$. Selanjutnya larutan tembaga tersebut diencerkan menjadi 25 ppm.

\section{Penentuan Pengaruh Variasi pH}

0,5 gram adsorben tongkol jagung dimasukan ke dalam erlenmeyer $100 \mathrm{~mL}$ dan ditambahkan larutan tembaga $50 \mathrm{~mL} 25 \mathrm{ppm}$ dengan berbagai $\mathrm{pH}$ yang divariasikan yaitu 1, 3, 5, 7 dan 9 selama 30 menit, adsorben dipisahkan dengan cara penyaringan. Filtrat selanjutnya dianalisis menggunakan spektroskopi serapan atom dengan panjang gelombang 324,7 nm dan perlakuan diulang sebanyak 3 kali (Lelifajri, 2010).

\section{Penentuan Pengaruh Variasi Waktu Kontak}

0,5 gram adsorben tongkol jagung sebanyak dimasukan ke dalam erlenmeyer dan ditambahkan larutan tembaga konsentrasi 25 ppm sebanyak $50 \mathrm{~mL}$ pada $\mathrm{pH}$ optimum yang telah diperoleh. Larutan dikocok menggunakan shaker dengan kecepatan pengadukan $400 \mathrm{rpm}$ dan variasi waktu 30, 45, 60, 75, 90 dan 105 menit. Adsorben kemudia dipisahkan dari larutan dengancara penyaringan. Filtrat selanjutnya dianalisis menggunakan spektroskopi serapan atom pada panjang gelombang 324,7 $\mathrm{nm}$ dan perlakuan diulang sebanyak 3 kali (Lelifajri, 2010).

\section{Analisis Data}

Analisis data yang digunakan pada penentuan $\mathrm{pH}$ optimum proses adsorpsi ditentukan dengan grafik daya serap adsorben dengan $\mathrm{pH}$ larutan, sedangkan penentuan waktu kontak optimum proses adsorpsi ditentukan dengan grafik daya serap adsorben dengan waktu kontak. Sementara untuk penetuan kapasitas absorpsi maksimum pada biomassa tongkol jagung terhadap logam $\mathrm{Cu}$ menggunakan persamaan isoterm absorpsi Langmuir.

Persamaan penetuan daya serap adsorpsi:

$\%$ Cu terserap $=\frac{(C i-C f)}{C i} \times 100 \%$

dimana $\mathrm{Ci}$ adalah konsentrasi awal (mg/L); Cf adalah konsentrasi akhir $(\mathrm{mg} / \mathrm{L})$; persamaan isotherm Langmuir

$$
\frac{1}{q e}=\frac{1}{q m \cdot K L} \cdot \frac{1}{C e}+\frac{1}{q m}
$$

dimana qe adalah jumlah tembaga yang teradsorpsi oleh adsorben $(\mathrm{mg} / \mathrm{g}) ; \mathrm{Ci}$ adalah konsentrasi tembaga pada keadaan setimbang (mg/L); qm adalah kapasitas maksimum adsorben $(\mathrm{mg} / \mathrm{g})$; dan KL adalah konstanta.

\section{Hasil dan Pembahasan}

\section{Pengukuran Optimasi $\mathrm{pH}$ pada Proses Adsorpsi Ion $\mathrm{Cu}^{2+}$ oleh Tongkol Jagung}

Penetuan $\mathrm{pH}$ optimum pada adsorpsi ion $\mathrm{Cu}$ ini bertujuan untuk mengetahui pada $\mathrm{pH}$ berapa daya serap adsorben dapat bekerja dengan maksimal. Uji variasi $\mathrm{pH}$ menggunakan larutan $\mathrm{Cu}$ berkonsetrasi 25 ppm dengan volume larutan sebanyak $50 \mathrm{~mL}$ ada masing-masing erlenmeyer di kondisikan pada $\mathrm{pH}$ 1, 3, 5, 7 dan 9 dengan massa adsorben tongkol jagung sebanyak 0,5 gram dan di lakukan pengandukan dengan kecepatan $400 \mathrm{rpm}$ selama 30 menit menggunakan shaker. Kecepatan pengadukan sangat berpengaruh penting dalam proses adsorpsi. Kecepatan pengadukan pada proses adsorpsi yang semakin rendah mengakibatkan kapasitas adsorpsinya semakin kecil. Kecepatan pengadukan yang terlalu cepat sebaliknya dapat mengakibatkan zat yang teradsorpsi akan mengalami desorpsi karena zat yang teradsorpsi akan terlepas dan tercampur kembali kedalam fluida (Da Mota, dkk., 2015). Kecepatan yang terlalu cepat dapat mengakibatkan struktur dari adsorben tersebut akan rusak (Haryanto, dkk., 2016). Sampel 
selanjutnya dianalisis menggunakan

spektrofotometri serapan atom GBC 932 AA

dengan panjang gelombang $324,7 \mathrm{~nm}$.

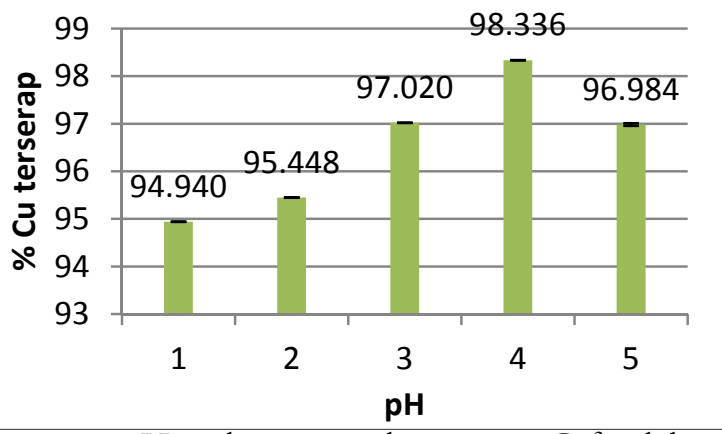

Gambar 1. Grafik optimasi $\mathrm{pH}$ pada proses adsorpsi ion $\mathrm{Cu}^{2+}$ oleh tongkol jagung

Hasil uji variasi derajat keasaman $(\mathrm{pH})$ menunjukan bahwa kemampuan penyerapan adsroben yang paling optimum terjadi pada $\mathrm{pH} 7$ dengan daya serap mencapai $98,336 \%$. Pada $\mathrm{pH} 1$ penyerapan adsorben memiliki daya serap yang paling rendah yaitu $94,940 \%$, kemudian meningkat pada $\mathrm{pH} 3$ daya serap adosrben menjadi sebesar $95,448 \%$ selanjutnya terjadi penaikan daya serap yang cukup signifikan yaitu pada $\mathrm{pH} 5$ sebesar $97,020 \%$. Daya serap yang rendah tersebut disebabkan karena penyerapan ion $\mathrm{Cu}$ (II) tidak bekerja secara maksimal pada larutan yang memiliki nilai $\mathrm{pH}$ asam dikarenakan konsentrasi $\mathrm{H}^{+}$yang terlalu tinggi sehingga gugus fungsi negatif akan bereaksi dengan $\mathrm{H}^{+}$dan menghalangi terikatnya ion $\mathrm{Cu}(\mathrm{II})$ (Martina, dkk., 2016). Sedangkan pada $\mathrm{pH}$ 9 daya serap kembali menurun menjadi sebesar 96,984 \%. Hal ini dikarenakan pada $\mathrm{pH} 9$ atau $\mathrm{pH}$ basa, ion $\mathrm{Cu}$ (II) akan mengendap membentuk $\mathrm{Cu}(\mathrm{OH})_{2}$ yang dapat menghalangi terjadinya adsorpsi sehingga ion logam $\mathrm{Cu}(\mathrm{II})$ tidak dapat terserap dengan baik (Wahyudianto, 2016).

$$
\mathrm{Cu}^{2+}{ }_{(a q)}+2 \mathrm{OH}^{-}(l) \rightarrow \mathrm{Cu}(\mathrm{OH})_{2(s)}
$$

Adsorpsi ion logam $\mathrm{Cu}(\mathrm{II})$ diuji menggunakan variasi $\mathrm{pH} \mathrm{1,} \mathrm{3,} \mathrm{5,} 7$ dan 9. Hasil menunjukan bahwa pada $\mathrm{pH}$ netral atau 7 ion $\mathrm{Cu}(\mathrm{II})$ dapat terserap secara maksmimal.
Pengukuran Optimasi Waktu Kontak pada Proses Adsorpsi Ion $\mathrm{Cu}^{2+}$ oleh Tongkol Jagung

Waktu adsorpsi adalah salah satu parameter dalam proses terjadinya adsorpsi karena waktu merupakan faktor yang dapat merefleksikan kinetika suatu adsorben dalam berinteraksi dengan adsorbat (Safrianti, dkk., 2012). Penentuan waktu kontak optimum pada adsorpsi ion tembaga ini bertujuan untuk mengetahui berapa lama waktu kontak yang dibutuhkan agar penyerapan logam oleh adsorben dapat terjadi secara maksmimal. Pengujian sebelumnya diperoleh $\mathrm{pH}$ optimum pada pH 7 dengan daya serap sebesar $98,336 \%$, sehingga akan digunakan larutan dengan $\mathrm{pH} 7$ untuk pengujian selanjutnya.

Pengujian variasi waktu kontak ini menggunakan larutan baku $\mathrm{pH} 7$ berkonsentrasi 25 ppm dengan volume $50 \mathrm{~mL}$ dengan kecepatan pengadukan $400 \mathrm{rpm}$ menggunakan shaker serta adsorben sebanyak 0,5 gram untuk masing-masing erlenmeyer. Pengujian variasi waktu kontak ini dikondisikan pada waktu 15 menit, 30 menit, 45 menit, 60, menit, 75 menit, 90 menit, dan 105 menit. Sampel dianalisis menggunakan spektrofotometri serapan atom GBC 932 AA dengan panjang gelombang $324,7 \mathrm{~nm}$.

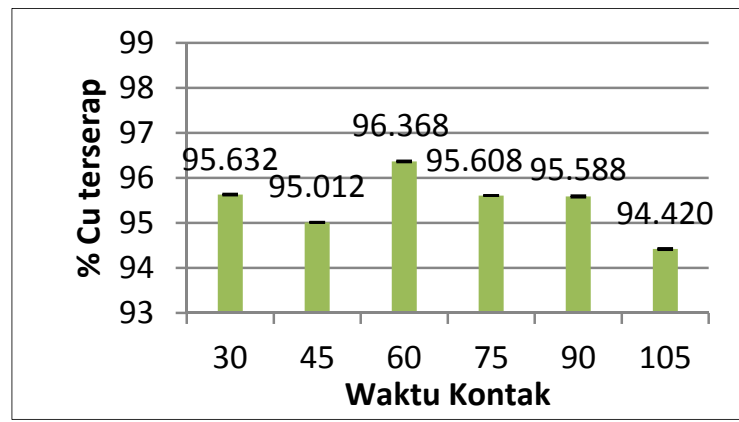

Gambar 2. Grafik optimasi waktu kontak pada proses adsorpsi ion $\mathrm{Cu}^{2+}$ oleh tongkol agung pada $\mathrm{pH} 7$. 
Logam $\mathrm{Cu}$ pada menit ke 30 mengalami penyerapan yang cukup bagus dengan daya serap absorben sebesar 95,632\%, selanjutnya pada menit ke 45 daya serap adsorben terhadap logam $\mathrm{Cu}$ mengalami penurunan menjadi sebesar $95,012 \%$. Penyerapan logam $\mathrm{Cu}$ selanjutnya mengalami peningkatan yang cukup signifikan dengandaya serap adsorben menjadi sebesar 96,368\%. Pengujian daya serap adsorpsi selanjutnya mengalami penurunan pada waktu 75, 90, dan 105 menit dengan daya serap berturut-turut menjadi sebesar 95,608; 95,588; dan 94,422\%. Hasil tersebut menunjukan bahwa waktu kontak optimum terjadi pada menit ke 60 yang dapat dilihat dari besarnya persentase daya serap adsorben terhadap logam $\mathrm{Cu}$. Adsorben dapat mengikat sebagian besar ion-ion logam yang ada pada larutan. Proses adsorpsi yang terjadi sebelum mencapai waktu optimum yaitu pada menit ke 30 dan 45 mengalami penaikan dan penurunan, hal ini disebabkan karenaadsorpsi yang terjadi bersifat reversible (bolak balik) sehingga daya serap adsorben menjadi tidak stabil (Syauqiah dkk., 2016). Setelah mencapai waktu optimum proses adsorpsi mengalami penurunan daya serap, hal ini terjadi karena adanya desorpsi atau pelepasan kembali ion yang berikatan dengan adsorben yang mengalami kejenuhan dimana pori dalam adsorben telah terisi penuh (Mohadi dkk., 2014). Waktu absorpsi terbaik yang diperoleh yaitu 60 menit, hasil ini sangat berbeda dengan hasil yang diperoleh dalam pengujian adsorpsi logam $\mathrm{Cu}$ menggunakan biomassa Phanerochaete chrysosporium dengan kondisi terbaik penyerapan logam $\mathrm{Cr}^{6+}$ adalah pada saat waktu 210 menit (Suprihatin, 2009).

Proses adsorpsi berdasarkan variasi waktu terjadi dalam dua tahap yaitu tahap awal yang berlangsung secara cepat yang menyebabkan daya serap meningkat, hal ini dilihat dari semakin besarnya kemampuan adsroben dalam menyerap ion logam $\mathrm{Cu}(\mathrm{II})$. Tahap kedua proses adsorpsimelambat dan menyebabkan daya serap menurun, dimana semakin menurunya kemampuan adsorben dalam menyerap ion logam $\mathrm{Cu}(\mathrm{II})$.

\section{Pengukuran Kapasitas Maksimum Adsorpsi Berdasarkan Persamaan Isotherm Adsorpsi Langmuir}

Penentuan kapasitas maksimum pada proses adropsi logam $\mathrm{Cu}$ oleh adsorben tongkol jagung menggunakan persamaan Isoterm Langmuir berdasarkan konsentrasi berdasarkan variasi waktu kontak.

Tabel 1. Data hasil adsorpsi $\mathrm{Cu}$ (II) terhadap adsorben tongkol jagung (Zea mays) berdasarkan Isoterm Langmuir

\begin{tabular}{ccccccc}
\hline $\begin{array}{c}\mathrm{Ci} \\
(\mathbf{m g} / \mathrm{L})\end{array}$ & $\begin{array}{c}\mathrm{Cf} \\
(\mathbf{m g} / \mathrm{L})\end{array}$ & $\begin{array}{c}\mathrm{V} \\
(\mathrm{L})\end{array}$ & $\begin{array}{c}\text { massa } \\
(\mathrm{gr})\end{array}$ & $\begin{array}{c}\mathrm{qe} \\
(\mathbf{m g} / \mathrm{g})\end{array}$ & $1 / \mathrm{cf}$ & $1 / \mathrm{qe}$ \\
\hline 25 & 1,092 & 0,05 & 0,5 & 2,3908 & 0,9157 & 0,4183 \\
25 & 1,247 & 0,05 & 0,5 & 2,3753 & 0,8019 & 0,4210 \\
25 & 0,908 & 0,05 & 0,5 & 2,4902 & 1,1013 & 0,4016 \\
25 & 1,098 & 0,05 & 0,5 & 2,3902 & 0,9107 & 0,4184 \\
25 & 1,103 & 0,05 & 0,5 & 2,3897 & 0,9066 & 0,4185 \\
25 & 1,395 & 0,05 & 0,5 & 2,3605 & 0,7168 & 0,4236 \\
\hline
\end{tabular}

Data diatas selanjutnya dibuat plot $1 / \mathrm{qe}$ terhadap 1/Cf, yang disajikan dalam kurva berikut

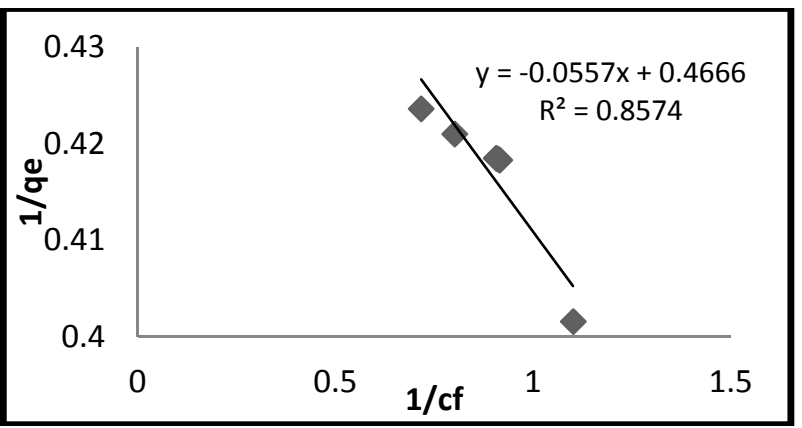

Gambar 3. Kurva linear isoterm langmuir adsorpsi $\mathrm{Cu}(\mathrm{II})$ dengan adsorben tongkol jagung (Zea mays). 
Model adsorpsi Langmuir dipilih untuk menentukan kapasitas maksimum adsorpsi tembaga oleh adsorben. Model isoterm Langmuir dikembangkan dengan asumsi bahwa jumlah permukaan yang dapat menampung absorbat adalah tetap, sesuai dengan luas permukaan adsorben dan bersifat bolak balik (reversible) (Tchobanoglous, 2003).

Hasil optimasi variasi $\mathrm{pH}$ dan waktu kontak selanjutnya digunakan untuk memperoleh kurva lineritas Langmuir, dengan memplotkan harga 1/qe (jumlah tembaga yang teradsorpsi oleh adsorben) terhadap 1/Cf (konsentrasi tembaga pada keadaan setimbang), sehingga dapat diperoleh harga tetapan kesetimbangan Langmuir KL dan kapasitas maksimum adsorpsi qm (mg/g) (Schmuhl, dkk., 2001).

Gambar 3 merupakan kurva linear isoterm Langmuir yang menghasilkan persamaan $\mathrm{y}=$ $0,055 x+0,466$ dengan nilai $R^{2}$ sebesar 0,857 . Dari hasil tersebut maka telah diketahui kapasitas maksimum absorpsi logam tembaga terhadap absorben tongkol jagung sebesar 2,1460 mg/g. Nilai qm menunjukan bahwa setiap satu gram absorben tongkol jagung dapat mengadsorpsi ion $\mathrm{Cu}(\mathrm{II})$ sebanyak $2,1460 \mathrm{mg}$.

\section{Kesimpulan}

Tongkol jagung dapat digunakan sebagai adsorben logam $\mathrm{Cu}(\mathrm{II}) . \mathrm{pH}$ optimum adsorpsi logam $\mathrm{Cu}(\mathrm{II})$ oleh absorben tongkol jagung terjadi pada $\mathrm{pH} 7$ dengan penyerapan sebesar 98,34\%, sedangkan waktu kontak optimum adsorpsi logam $\mathrm{Cu}$ (II) oleh tongkol jagung terjadi pada menit ke 60 dengan persentase logam tembaga yang terserap sebesar 96,37\%. Kemudian kapasitas maksimum adsorpsi tongkol jagung terhadap ion $\mathrm{Cu}(\mathrm{II})$ sebesar $2,4160 \mathrm{mg} /$ gram.

\section{Ucapan Terima Kasih}

Ucapan terimakasih penulis berikan kepada semua pihak yang banyak membantu penulis dalam menyelesaikan penelitian ini.

\section{Referensi}

Amin, A., Sitorus, S., \& Yusuf, B. (2016). Pemanfaatan limbah tongkol jagung (zea mays 1.) sebagai arang aktif dalam menurunkan kadar amonia, nitrit dan nitrat pada limbah cair industri tahu menggunakan teknik celup. Jurnal Kimia Mulawarman, 13(2), 78-84.

Amiruddin, H. (2016). Modifikasi permukaan karbon aktif tongkol jagung (zea mays) dengan $\mathrm{HNO}_{3}, \mathrm{H}_{2} \mathrm{SO}_{4}$, dan $\mathrm{H}_{2} \mathrm{O}_{2}$ sebagai bahan elektroda superkapasitor. Makassar: Hasanuddin University Repository.

Haryanto, B., Panjaitan, F., Haloho, H., Rawa, R., \& Ridho, M. (2016). Kajian kemampuan adsorpsi batang jagung (zea mays.) terhadap ion logam kadmium $\left(\mathrm{Cd}^{2+}\right)$. Jurnal Teknologi Pertanian Andalas, 20(1), 59-68.

Lelifajri, L. (2010). Adsorpsi ion logam $\mathrm{Cu}(\mathrm{II})$ menggunakan lignin dari limbah serbuk kayu gergaji. Jurnal Rekayasa Kimia \& Lingkungan, 7(3), 126-129.

Ligawati, L. (2016). Analisis produksi dan konsumsi jagung domestik dalam rangka pencapaian swasembada jagung nasional tahun 2017. Bogor: Institut Pertanian Bogor.

Martina, D., Hastuti, R., \& Widodo, D. S. (2016). Peran adsorben selulosa tongkol jagung (zea mays) dengan polivinil alkohol (PVA) untuk penyerapan ion logam timbal $\left(\mathrm{Pb}^{2+}\right)$. Jurnal Kimia Sains dan Aplikasi, 19(3), 77-82.

Mohadi, R., Saputra, A., Hidayati, N., \& Lesbani, A. (2014). Studi interaksi ion logam Mn2+ dengan selulosa dari kayu. Jurnal Kimia, $8(1), 1-8$.

Mota, I. D. O. D., Castro, J. A. D., Casqueira, R. D. G., \& Junior, A. G. D. O. (2015). Study of electroflotation method for treatment of wastewater from washing soil contaminated by heavy metals. Journal of Materials Research and Technology, 4(2), 109-113.

Muchtaridi. (2016). Exploring kimia SMA kelas XII. Jakarta: Yudistira.

Ningsih, D. A., Said, I., \& Ningsih, P. (2016). Adsorpsi logam timbal $(\mathrm{Pb})$ dari larutannya dengan menggunakan adsorben dari tongkol jagung. Jurnal Akademika Kimia, 5(2), 5560.

Nuriadi, N., Napitupulu, M., \& Rahman, N. (2013). Analisis logam tembaga $(\mathrm{Cu})$ pada buangan limbah tromol (tailing) pertambangan Poboya. Jurnal Akademika Kimia, 2(2), 90-96.

Nurmalasari, D., Hastuti, R., \& Widodo, D. S. (2015). Pengaruh penambahan polivinil alkohol pada biomassa tongkol jagung-bulu ayam sebagai adsorben campuran ion logam tembaga dan kromium. Jurnal Kimia Sains dan Aplikasi, 18(1), 18-23.

Safrianti, I., Wahyuni, N., \& Zaharah, T. A. (2012). Adsorpsi timbal (II) oleh selulosa limbah jerami padi teraktivasi asam nitrat: Pengaruh $\mathrm{pH}$ dan waktu kontak. Jurnal Kimia Khatulistiwa, 1(1), 1-7.

Schmuhl, R., Krieg, H., \& Keizer, K. (2001). Adsorption of $\mathrm{Cu}(\mathrm{II})$ and $\mathrm{Cr}(\mathrm{VI})$ ions by 
chitosan: Kinetics and equilibrium studies. Water $S A, 27(1), 1-8$.

Sukardjo. (2013). Kimia fisika. Yogyakarta: Rineka Cipta.

Suprihatin, E. A. (2009). Biosorpsi logam Cu(II) dan $\mathrm{Cr}(\mathrm{VI})$ pada limbah elektroplating dengan menggunakan biomassa phanerochaete chrysosporium. Jurnal Teknik Kimia, 4(1), 250-254.

Surono, U. B. (2010). Peningkatan kualitas pembakaran biomassa limbah tongkol jagung sebagai bahan bakar alternatif dengan proses karbonisasi dan pembriketan. Jurnal Rekayasa Proses, 4(1), 13-18.

Svehla, G. (1990). Buku teks analisis anorganik kualitatif makro dan mikro edisi kelima. Jakarta: PT Kalman Media Pusaka.

Syauqiah, I., Amalia, M., \& Kartini, H. A. (2016). Analisis variasi waktu dan kecepatan pengaduk pada proses adsorpsi limbah logam berat dengan arang aktif. Info Teknik, 12(1), 11-20.
Tchobanoglous, G., Burton, F. L., \& Stensel, H. D. (2003). Wastewater engineering treatment and reuse, fourth edition. USA: McGraw-Hill Companies Inc.

Veeramachineni, A., Sathasivam, T., Muniyandy, S., Janarthanan, P., Langford, S., \& Yan, L. (2016). Optimizing extraction of cellulose and synthesizing pharmaceutical grade carboxymethyl sago cellulose from Malaysian sago pulp. Applied Sciences, 6(6), 170.

Wahyudianto, F. E. (2016). Studi pemanfaatan limbah cangkang kerang dara (Anandara granosa) sebagai adsorben $\mathrm{Pb}^{2+}, \mathrm{Cu}^{2+}$, dan $\mathrm{Zn}^{2+}$. Tesis. Surabaya: Institut Teknologi Sepuluh November.

Widodo, W. (2008). Pencemaran air raksa (Hg) sebagai dampak pengolahan bijih emas di sungai Ciliunggunung, Waluran, kabupaten Sukabumi. Indonesian Journal on Geoscience, 3(3), 139-149. 